\title{
SISTEM PENDETEKSI EPILEPSI DENGAN ALGORITMA K-MEANS CLUSTERING SEBAGAI PENDETEKSI PENYAKIT BERBASIS SISTEM PAKAR PADA MASA PANDEMI COVID-19
}

\author{
TM Johan ${ }^{1)}$ \\ ${ }^{1)}$ Program Studi Informatika, Fakultas Ilmu Komputer, Universitas Almuslim Bireuen \\ e-mail: johantm1959@gmail.com
}

\begin{abstract}
[Expert System Diagnosis of Epilepsy Disease using Web-Based K-Means Clustering Method] The influence of the development of computer science has touched various fields, for example in the fields of medicine, military and others. Given the rapid development of increasingly advanced technology, especially in the field of computers, many people use computers as a tool. Also included in the field of medicine, computers have been included in it as a tool to do a job or identify a certain disease that facilitates human work. To determine the type of disease and how to overcome it and use the Waterfall method for system development. This expert system will also use the K-Means Clustering concept. This application is made using the PHP programming language and the MySQL database as a place to store the data needed in making applications. Adobe Dreamweaver for Web design. This research produces an expert system application to diagnose epilepsy based on a web so that it can help users to obtain the desired information. The preparation of this expert system is in the form of users and admins. Through this system, the user can identify the disease based on the symptoms that attack it. The system also has the ability to add, update, and delete features and symptoms on it along with the results of consultations carried out by the admin.
\end{abstract}

Keywords: Expert System; K-Means Clustering; Epilepsy; PHP; MySQL.

\begin{abstract}
Abstrak
Pengaruh perkembangan ilmu komputer telah menjamah berbagai bidang, contohnya saja pada bidang kedokteran, militer dan lain-lain. Mengingat semakin pesatnya perkembangan teknologi yang semakin maju khususnya dibidang komputer, maka banyak orang yang memanfaatkan komputer sebagai alat bantu. Tidak ketinggalan juga termasuk dalam bidang kedokteran, komputer telah masuk didalamnya sebagai alat bantu untuk mengerjakan suatu pekerjaan ataupun melakukan identifikasi suatu penyakit tertentu yang memudahkan pekerjaan manusia. Untuk menentukan jenis penyakit dan cara penanggulangannya serta menggunakan metode Waterfall untuk pengembangan sistemnya. Sistem pakar ini juga akan menggunakan konsep K-Means Clustering Aplikasi ini dibuat dengan menggunakan bahasa pemrograman PHP dan database MySQL sebagai tempat penyimpanan data-data yang dibutuhkan dalam pembuatan aplikasi. Adobe Dreamweaver untuk desain Web. Penelitian ini menghasilkan aplikasi sistem pakar mendiagnosa penyakit epilepsi berbasis web sehingga dapat membantu user untuk memperoleh informasi yang diinginkan. Penyusunan sistem pakar ini berupa user dan admin. Melalui sistem ini, user dapat mengidentifikasi penyakit berdasarkan gejala-gejala yang menyerangnya. Sistem juga mempunyai kemampuan untuk menambah, mengupdate, serta menghapus ciri dan gejala pada la beserta hasil konsultasi yang dilakukan oleh admin.
\end{abstract}

Kata Kunci: Sistem Pakar; K-Means Clustering; Epilepsi; PHP; MySQL. 


\section{Pendahuluan}

Epilepsi adalah gangguan kronik otak yang menunjukkan gejala-gejala berupa serangan yang berulangulang terjadi akibat adanya ketidaknormalan kerja sementara sebagian atau seluruh jaringan otak karena cetusan listrik pada neuron (sel saraf) peka rangsang yang berlebihan, yang dapat menimbulkan kelainan motorik, sensorik, otonom atau psikis yang timbul tiba-tiba dan sesaat disebabkan lepasnya muatan listrik abnormal sel-sel otak (Kristanto, 2017; Lukas, Harsono, \& Astuti, 2016; Suwarba, 2016)

Penyakit Epilepsi dapat menyerang dari masa kanak-kanak dengan adanya riwayat ibu yang menggunakan obat antikonvulsan yang digunakan sepanjang kehamilan dan juga adanya riwayat penyakit pada masa kanak-kanak (Andrian, 2019; Hardiyanti, 2020). Oleh karena itu, penyakit ini dapat menyerang pada tanpa mengenal batasan usia (Mulyawati, 2014). Bisa dimulai pada masa anak-anak atau pada masa remaja dan dewasa (Purba, Siagian, \& Tarigan, 2017).

Salah satu solusi dalam penanggulangan Epilepsi ialah menentukan dengan pasti diagnosis Epilepsi (Sunaryo, 2007; Suwarba, 2016). Untuk mengetahui tentang penyakit Epilepsi penderita membutuhkan pakar atau ahli tentang penyakit Epilepsi. Seorang pakar memiliki keahlian analisa tentang penyakit dengan akurat dalam memberikan informasi pada penderita penyakit Epilepsi.

Untuk lebih mempermudah dalam memastikan penyakit yang diderita oleh pasien, dibutuhkan sebuah alat bantu yang mendukung dalam melakukan diagnose, baik yang dapat digunakan secara lansung oleh Pasien atau dapat digunakan oleh Pakar / Dokter untuk menentukan penyakit Epilepsi dengan secara tepat dan cepat sehingga dapat diputuskan pengobatan secara efektif. Dalam penelitian ini dikembangkan suatu sistem pakar berbasis komputer untuk mendeteksi dan mendiagnosa penyakit epilepsi tanpa harus bertemu dengan pakar epilepsi secara langsung. Aplikasi yang berbasis sistem pakar ini dikembangkan dengan menggunakan metode K-Means Clustering dan bahasa pemrograman PHP dan MySQL sebagai bahasa pemrogramannya. Diharapkan aplikasi ini dapat membantu masyarakat dalam mendiagnosa penyakit epilepsi tanpa harus berkunjung ke rumah sakit, dikarenakan saat ini sedang meningkatnya kasus warga yang positif Covid-19 dan dirawat di rumah sakit.

\section{Metode}

A. Metode K-Means Clustering

$K$-Means adalah Metode yang mempartisi data ke dalam cluster/kelompok sehingga data yang memiliki karakteristik yang sama dikelompokkan ke dalam satu cluster yang sama dan data yang mempunyai karakteristik yang berbeda dikelompokkan ke dalam kelompok yang lain (Pham, Dimov, \& Nguyen, 2005). Tujuan dari data clustering ini adalah untuk meminimalisasikan objective function yang diset dalam proses clustering, yang pada umumnya berusaha meminimalisasikan variasi di dalam suatu cluster dan memaksimalisasikan variasi antar cluster (Likas, Vlassis, \& Verbeek, 2003).

Data clustering menggunakan metode $K$-Means ini secara umum dilakukan dengan algoritma dasar sebagai berikut (Na, Xumin, \& Yong, 2010):

1. Tentukan jumlah cluster

2. Alokasikan data ke dalam cluster secara random

3. Hitung centroid/rata-rata dari data yang ada di masing-masing cluster

4. Alokasikan masing-masing data ke centroid/rata-rata terdekat

5. Kembali ke Step 3, apabila masih ada data yang berpindah cluster atau apabila perubahan nilai centroid, ada yang di atas nilai threshold yang ditentukan atau apabila perubahan nilai pada objective function yang digunakan di atas nilai threshold yang ditentukan

Untuk menghitung centroid cluster ke-i, $i v$, digunakan rumus sebagai berikut (Dasgupta, 2008):

dimana:

$$
v_{i j}=\frac{\sum_{\mathrm{K}=1}^{\mathrm{N}_{\mathrm{i}}} \mathrm{X}_{\mathrm{kj}}}{\mathrm{N}_{\mathrm{i}}}
$$

$N i:$ Jumlah data yang menjadi anggota cluster ke- $i$

B. Analisa Sistem Lama

Analis sistem adalah seseorang yang bertanggung jawab atas penelitian, perencanaan, pengkoordinasian, dan merekomendasikan pemilihan perangkat lunak dan sistem yang paling sesuai dengan kebutuhan organisasi bisnis atau perusahaan. Analis sistem memegang peranan yang sangat penting dalam proses pengembangan sistem. Seorang analis sistem harus memiliki setidaknya empat keahlian: analisis, teknis, manajerial, dan interpersonal (berkomunikasi dengan orang lain). Kemampuan analisis memungkinkan seorang analis sistem 
untuk memahami perilaku organisasi beserta fungsi-fungsinya, pemahaman tersebut akan membantu dalam mengidentifikasi kemungkinan terbaik serta menganalisis penyelesaian permasalahan.

Pada saat ini, sistem pemeriksaan masih menggunakan sistem manual. Untuk proses pemeriksaan pasien secara manual, pasien datang ke tempat praktek dokter penyakit Epilepsi untuk bertanya keluhan-keluhan yang dialami oleh pasien kemudian pasien diperiksa secara fisik oleh dokter tersebut, jika ternyata pasien mempunyai tanda-tanda adanya penyakit Epilepsi maka dokter akan memberikan resep obat dan juga saran untuk mencegah resiko penyakit Epilepsi yang diderita pasien kemudian pasien membayar resep dan jasa dokter. Apabila ternyata pasien tidak menderita penyakit Epilepsi maka pasien juga tetap membayar jasa pemeriksaan oleh dokter.

C. Analisa Data

Analisis data pendiagnosa penyakit Epilepsi ini bertujuan untuk menerapkan solusi pemecahan masalah yang akan diberikan. Keberhasilan berbasis sistem pakar terletak pada pengetahuan dan bagaimana mengolah pengetahuan tersebut agar ditarik kesimpulan. Pengetahuan yang diperoleh dari hasil wawancara dan analisa lewat buku di konversi ke dalam sebuah tabel jenis penyakit yang terjadi pada Epilepsi dan gejala guna mempermudah proses pencarian solusi.

1. Eksternal

Data eksternal merupakan data yang di ambil penulis dari sumber luar yaitu dari buku, jurnal, dan internet. Penulis mengambil referensi internet dan buku untuk proses perancangan sistem dan juga pengertian dari sistem pakar dengan metode yang di gunakan dalam analisa sistem.

2. Internal

Data internal merupakan data yang di ambil penulis dari sumber tempat penulis membuat penelitian dalam hal ini penulis mengambil data pada Rumah Sakit Daerah dr. Fauziah Bireuen. Data yang penulis ambil berupa data penyakit epilepsi, data gejala epilepsi dan cara penanganannya. Berikut ini beberapa jenis penyakit epilepsi dan gejala epilepsi

Tabel 1. Kesimpulan Penelusuran

\begin{tabular}{|l|l|}
\hline Kode & Keterangan \\
\hline $\mathrm{P} 01$ & Epilepsi Simtofatik \\
$\mathrm{P} 02$ & Epilepsi Idiopatik \\
$\mathrm{P} 03$ & Epilepsi Kriptogenik \\
\hline
\end{tabular}

Tabel 2. Gejala

\begin{tabular}{|c|l|c|}
\hline Gejala & Keterangan & Bobot \\
\hline G01 & Pandangan Mata Kosong & 35 \\
\hline G02 & Gemetar Pada Tubuh & 67 \\
\hline G03 & Kandung Kemih yang hilang kontrol & 56 \\
\hline G04 & Nyera pada bagian otot & 60 \\
\hline G05 & Kejang -kejang & 80 \\
\hline G06 & Kesadaran akan menghilang & 69 \\
\hline G07 & Bingung temporer & 75 \\
\hline G08 & Sulit bernafas & 50 \\
\hline G09 & Muka yang membiru & 78 \\
\hline G10 & Busa akan keluar melalui mulutnya & 60 \\
\hline
\end{tabular}


D. Proses Pencarian

Rule Base biasanya dituliskan dalam bentuk jika - maka (IF - THEN). Kaidah dapat dikatakan sebagai hubungan implikasi dua bagian yaitu premis (jika) dan bagian konklusi (maka). Apabila bagian premis dipenuhi maka bagian konklusi juga akan bernilai benar. Sebuah kaidah terdiri dari klausa klausa sebuah klausa mirip sebuah kalimat subjek, kata kerja dan objek yang menyatakan suatu fakta ada sebuah klausa premis dan klausa konklusi pada sebuah kaidah.

\section{Rule 1:}

IF Pandangan Mata Kosong
AND Gemetar Pada Tubuh
AND Kandung Kemih yang hilang kontrol
AND Nyera pada bagian otot
AND Kejang -kejang
AND Muka yang membiru
THEN Epilepsi Simtofatik

Rule 2 :

IF Muka yang membiru

AND Sulit bernafas

$A N D$ Kandung Kemih yang hilang kontrol

$A N D$ Nyera pada bagian otot

$A N D$ Kejang -kejang

$A N D$ Busa akan keluar melalui mulutnya

THEN Epilepsi Idiopatik

Pencarian Manual Metode K-Means Custering

[R1] : IF sakit tubuh THEN epilepsi (cf : 0.40)

[R2] : IF nafsu makan berkurang THEN epilepsi (cf : 0.50)

[R3] : IF pilek THEN epilepsi (cf : 0.75)

[R4] :IF demam THEN epilepsi (cf : 0.60)

Tentukan Nilai dari CF gabungannya:

Jawab:

$$
\begin{aligned}
\text { a. R1 dan R2 :: CFc }(\mathrm{CF} 1, \mathrm{CF} 2) & =\mathrm{CF} 1+\mathrm{CF} 2(1+\mathrm{CF} 1) \\
& =-0,40+(-0,50)(1+(-0,40)) \\
& =-0,40+(-0,50)(0,60) \\
= & -0,40-0,30
\end{aligned}
$$

$=-0,70$

b. R3 dan R4 :: CFc (CF1,CF2) = CF1 + CF2 (1- CF1)

$=0,75+0,6(1-0,75)$

$=0,75+0,6 \cdot 0,25$

$=0,75+0,15$

$=0,9$....

c. Gabungkan (a) dan (b) :: CFc $(\mathrm{CF} 1, \mathrm{CF} 2)=(\mathrm{CF} 1+\mathrm{CF} 2) /(1-\min (|\mathrm{CF} 1|,|\mathrm{CF} 2|))$

$=(-0,70+0,9) /(1-\min (|-0,70|,|0,90|))$

$=0,20 /(1-(0,70))$

$=0,20 / 0,30$

$=0,67$

Kesimpulannya: Suatu penyakit epilepsi disebabkan oleh gejala-gejala tersebut di atas memiliki nilai Clustering sebesar 0,67. Maka pasien mengalami penyakit Epilepsi Idiopetik

\section{Hasil dan Pembahasan}

A. Implementasi

Pada halaman ini terdiri dari beberapa menu yaitu sebagai berikut :

1. Halaman Utama Sistem

Halaman ini merupakan halaman utama yang tampil di saat sistem dijalankan, pada halaman ini terdapat beberapa menu yaitu menu beranda, menu jenis penyakit, menu konsultasi, menu help dan buku tamu sebagimana gambar di bawah ini. 


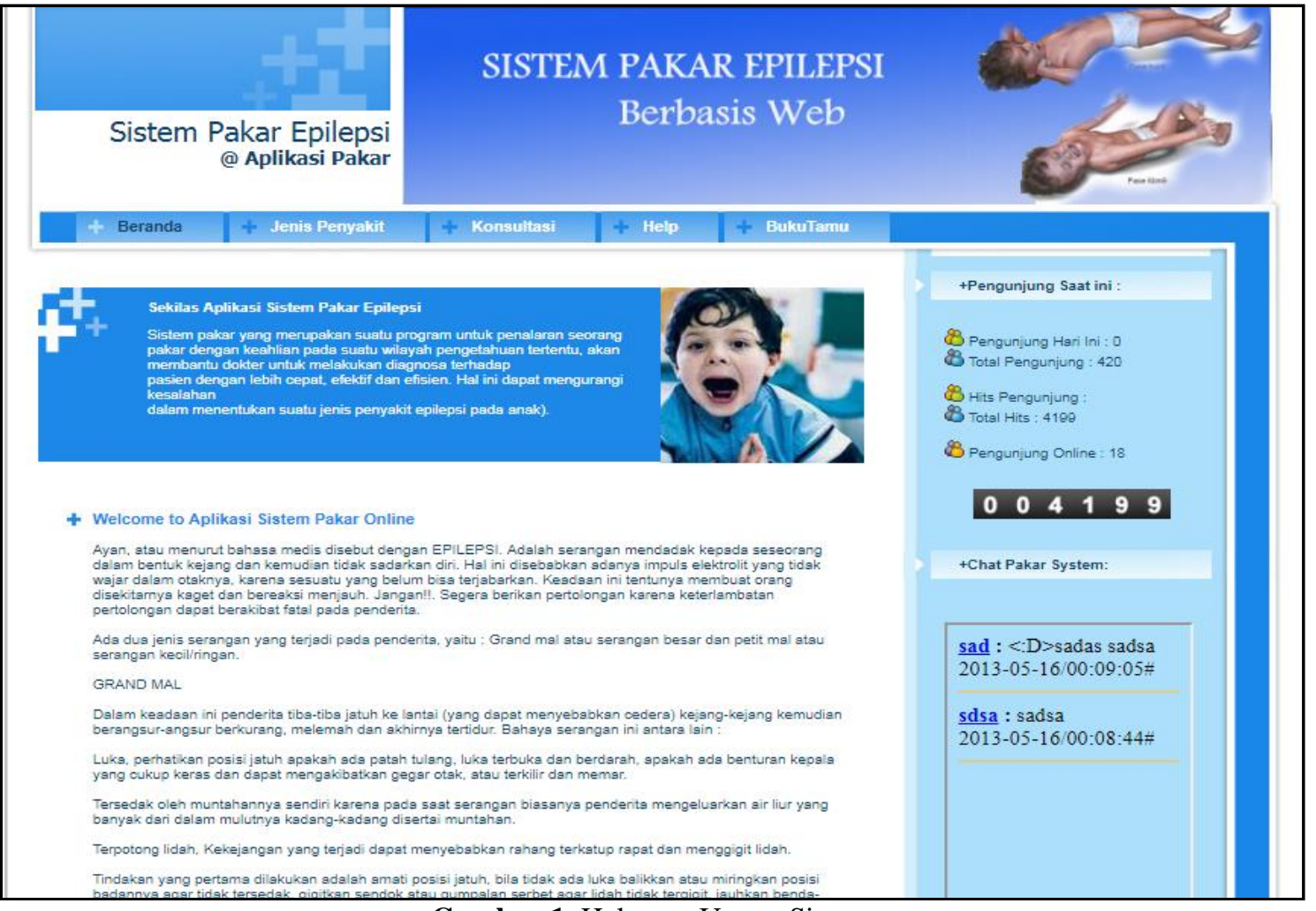

\section{Gambar 1. Halaman Utama Sistem}

2. Halaman Daftar Penyakit

Halaman ini merupakan halaman yang menampilkan daftar penyakit epilepsi pada sistem pakar diagnosa penyakit epilepsi yang di tampilkan berupa kode penyakit, nama penyakit dan nama latin sebagimana gambar di bawah ini.

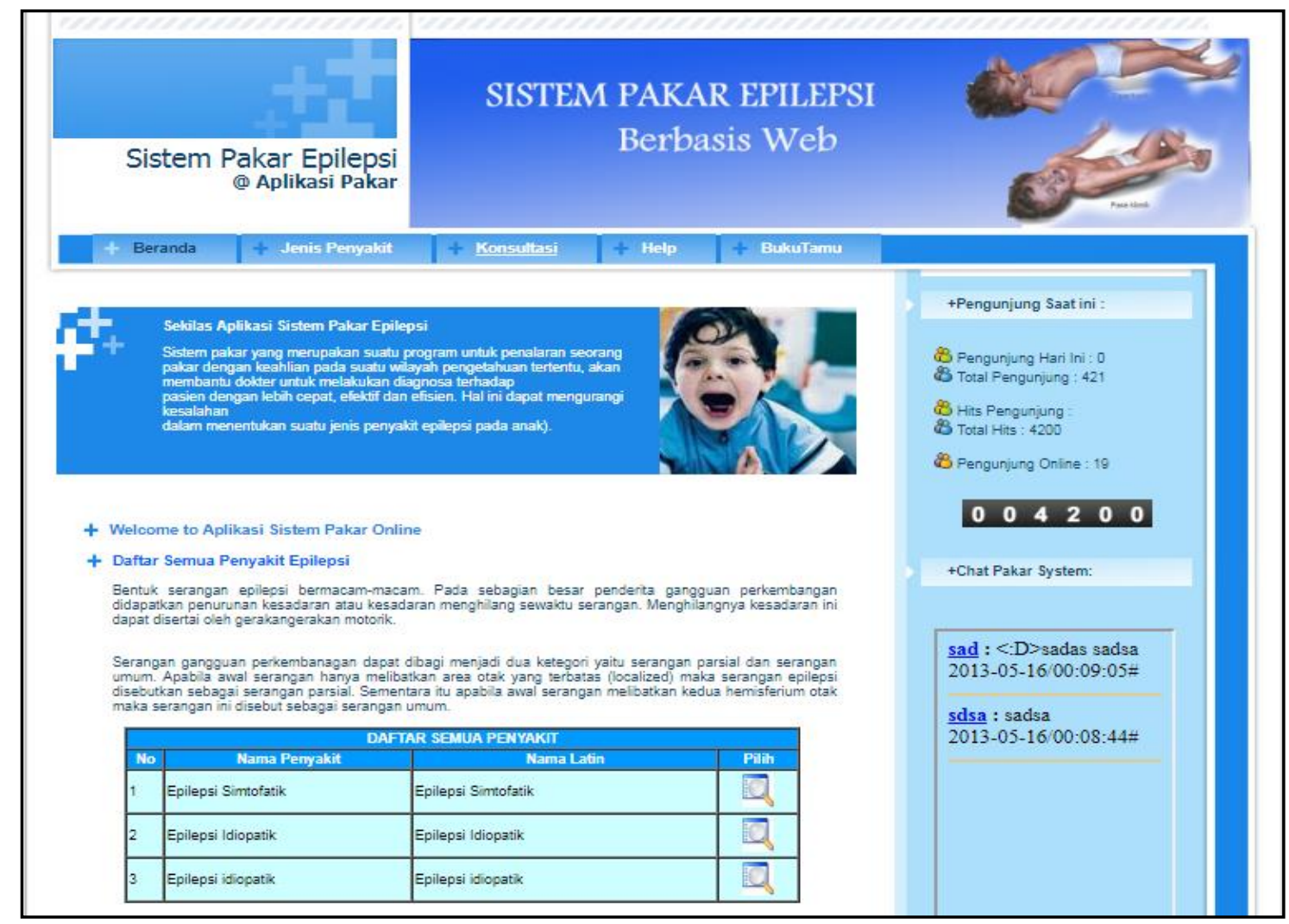

Gambar 2. Halaman Daftar Penyakit 
3. Halaman Daftar Gejala

Halaman ini merupakan halaman yang menampilkan daftar gejala epilepsi pada sistem pakar diagnosa penyakit epilepsi yang di tampilkan berupa kode gejala, nama gejala dan nama penyakit yang berelasi dengan gejala tersebut. sebagimana gambar 4.3 di bawah ini.

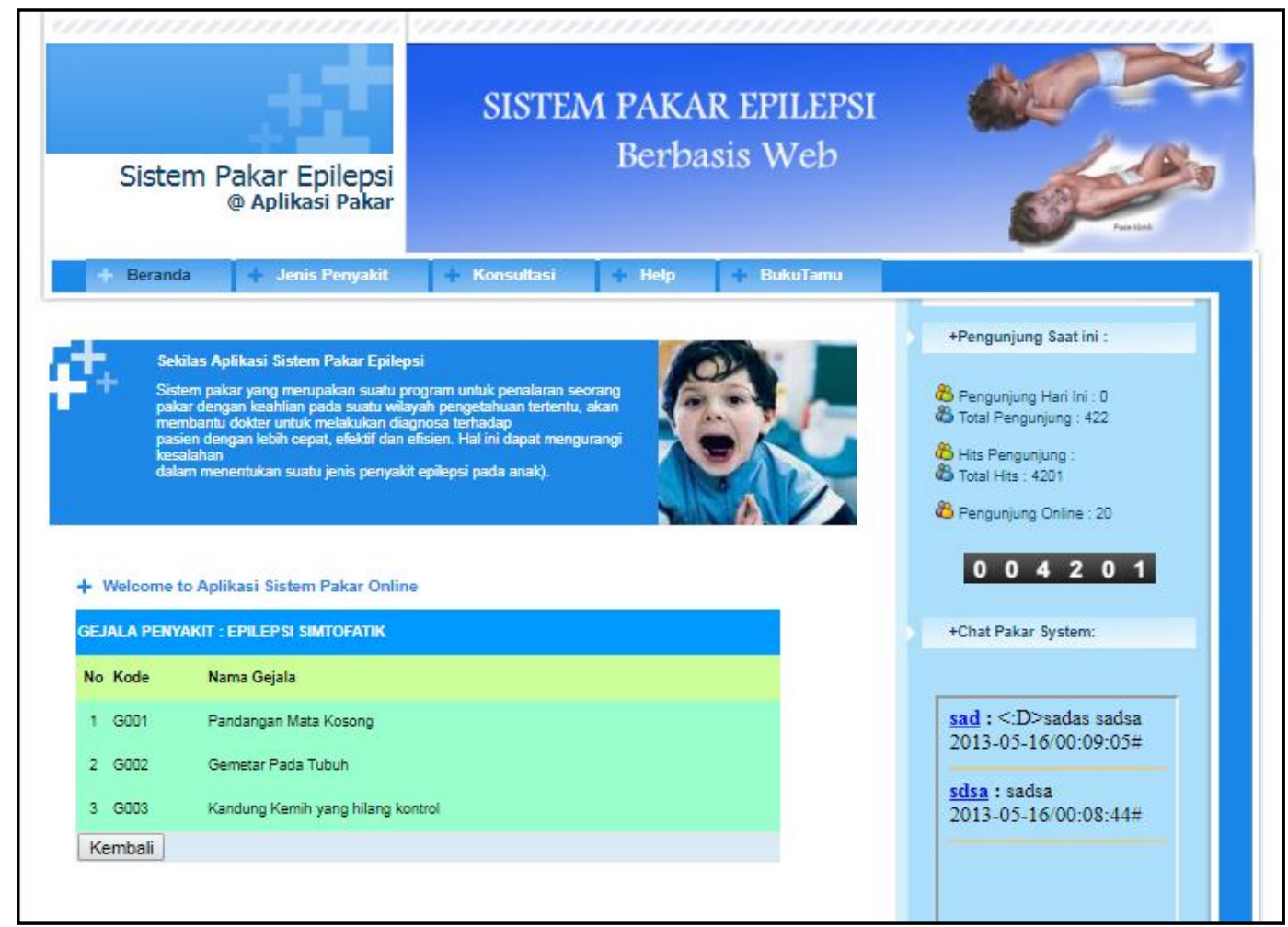

Gambar 3. Halaman Daftar Gejala

4. Halaman Petunjuk

Halaman ini merupakan halaman yang menampilkan petunjuk penggunaan sistem pakar diagnosa penyakit epilepsi, untuk lebih jelas dapat dilihat pada gambar berikut.

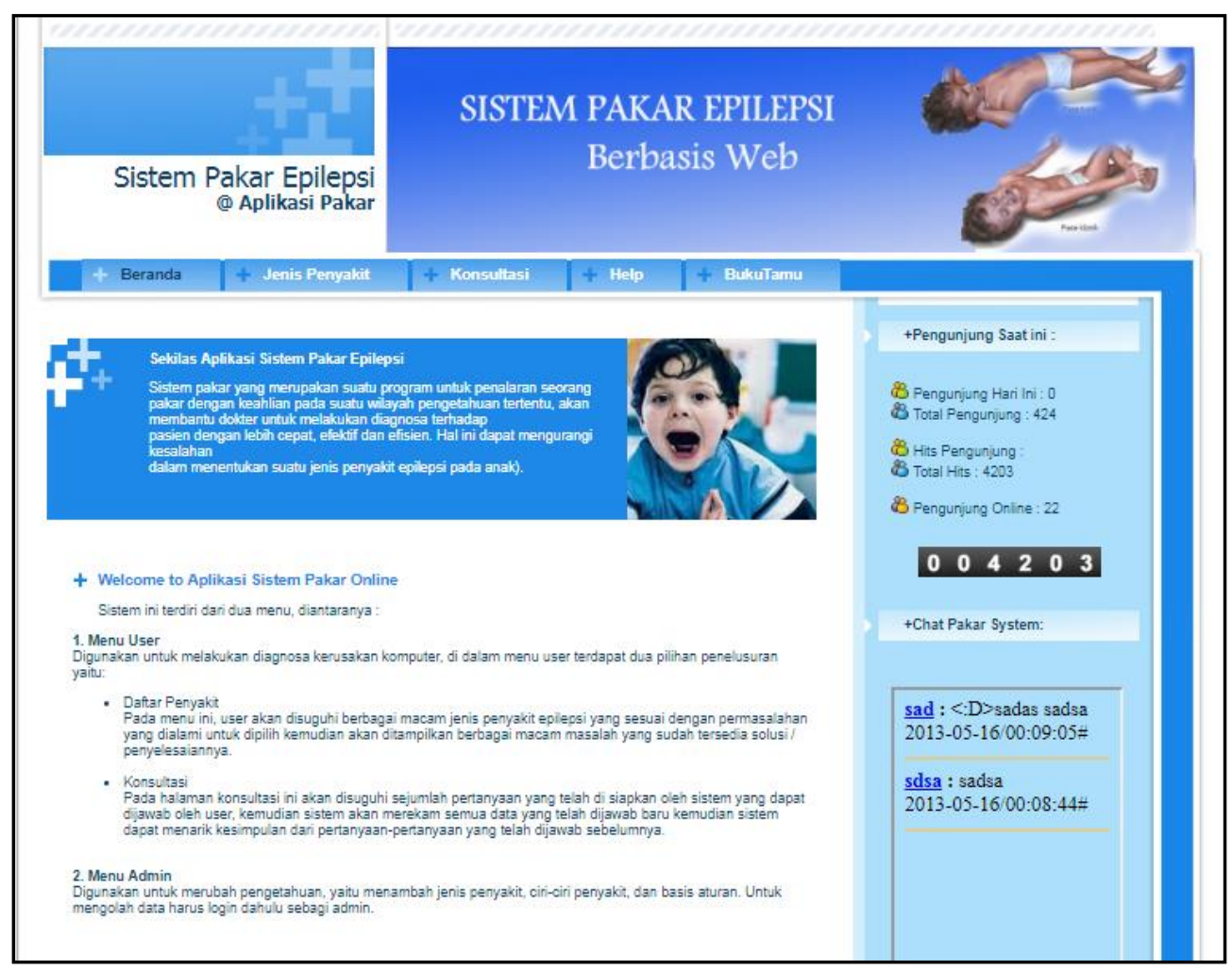


Gambar 3. Halaman Bantuan Penggunaan Sistem

5. Halaman Registrasi User

Halaman ini merupakan halaman yang befungsi sebagai registrasi user yang menyediakan beberapa text file untuk identitas user, untuk lebih jelas dapat dilihat pada gambar berikut.

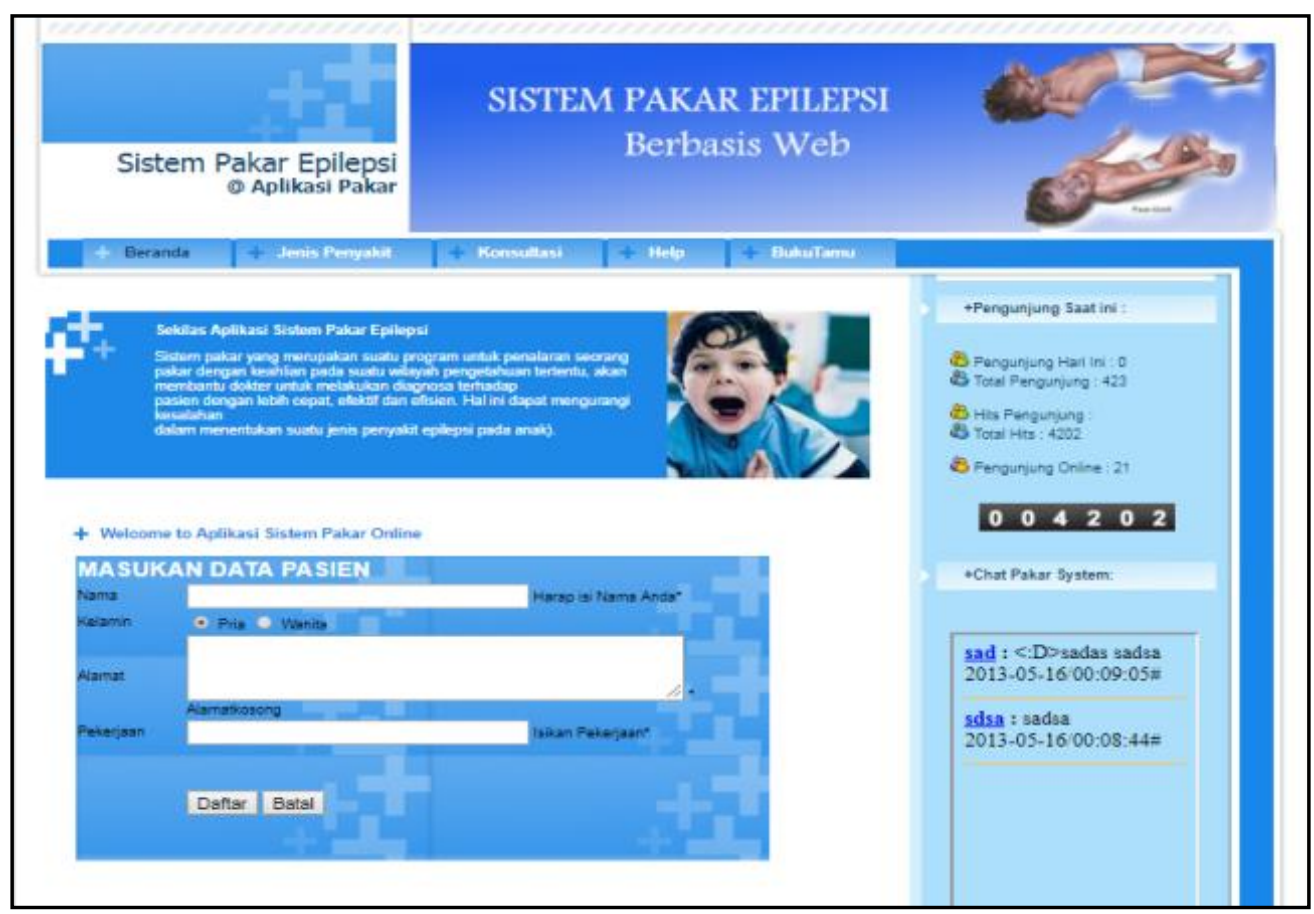

Gambar 4. Halaman Registrasi User

6. Halaman Diagnosa Penyakit

Halaman ini merupakan halaman untuk diagnosa penyakit epilepsi, dengan menjawab gejala - gejala yang ada pada penyakit epilepsi tersebu, sehingga menghasilkan hasil diagnosa sebagaimana gambar berikut ini :

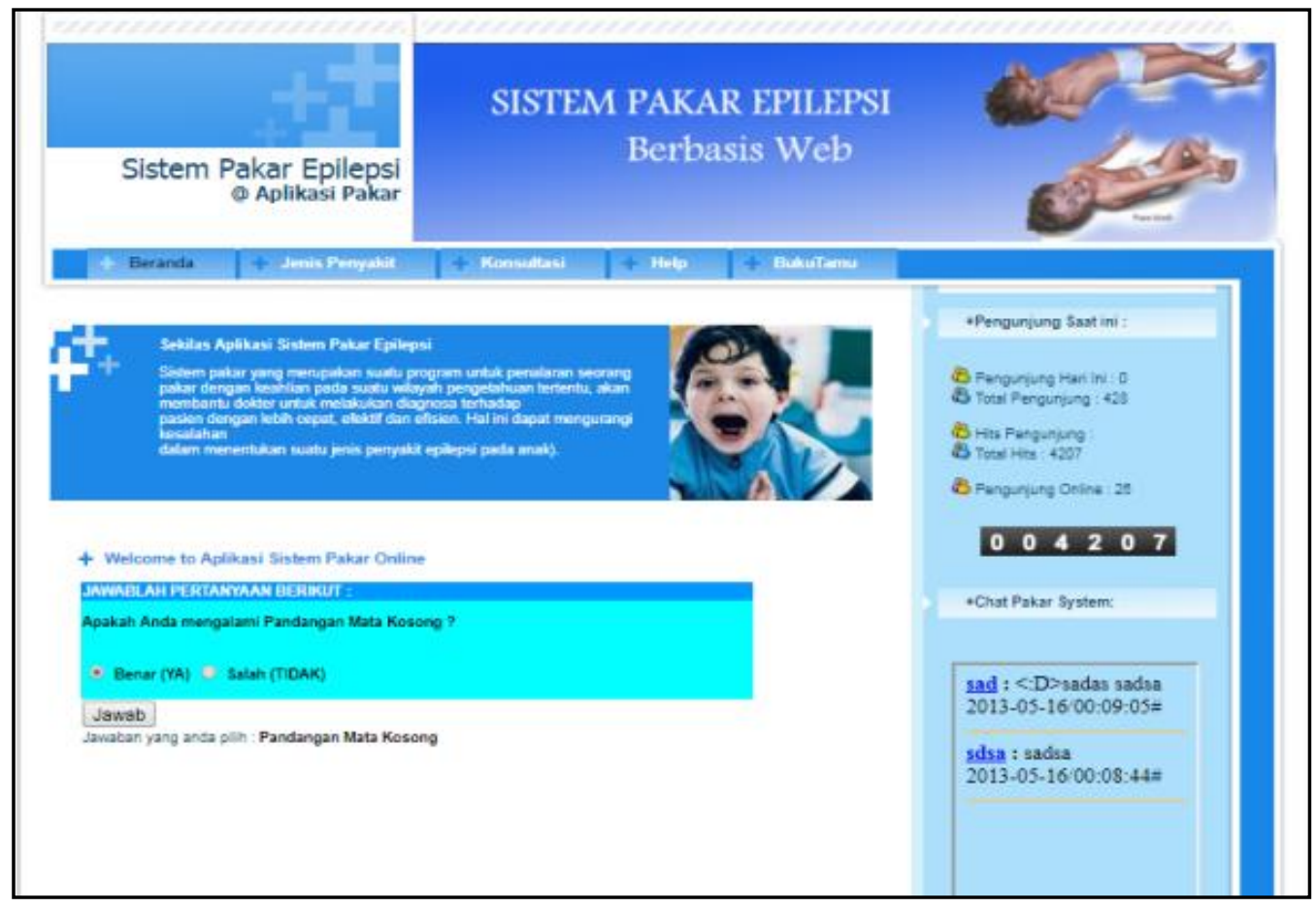

Gambar 5. Halaman Diagnosa 
7. Halaman Hasil Diagnosa Penyakit

Setelah melakukan diangnosa dengan beberapa gejala sehingga menghasilkan hasil diagnosa berupa penyakit yang di alami pasien dan solusi untuk mengatasinya sebagaimana gambar berikut ini :

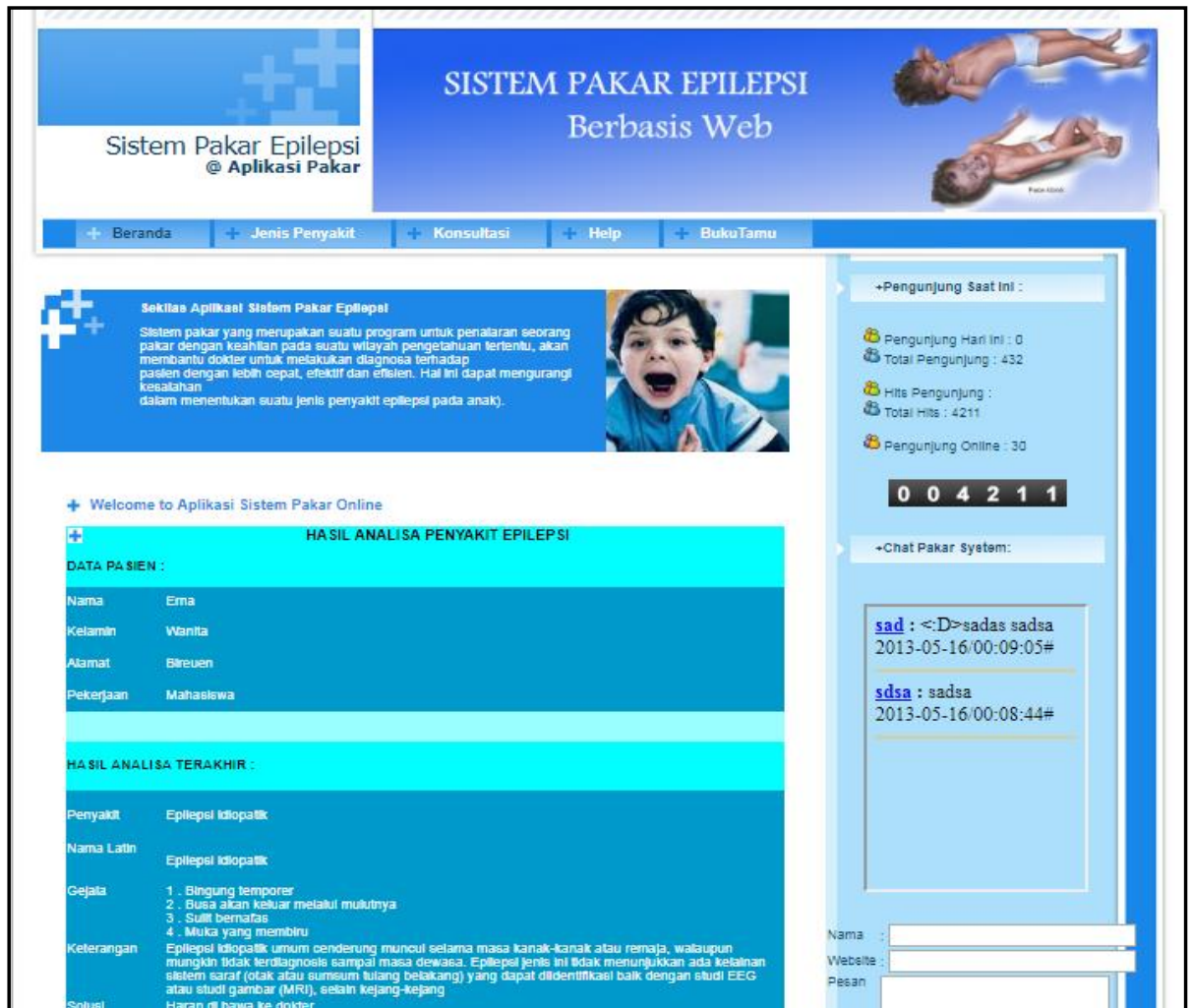

8. Login Administrator

Gambar 6. Halaman Hasil Diagnosa

Halaman ini merupakan halaman login administrator untuk masuk ke dalam sistem dengan memasukkan username dan password, jika username dan password yang dimasukkan valid maka admin masuk ke sistem dan jika username dan password yang dimasukkan tidak valid makan admin harus login kembali. Berikut tampilan halaman login administrator.

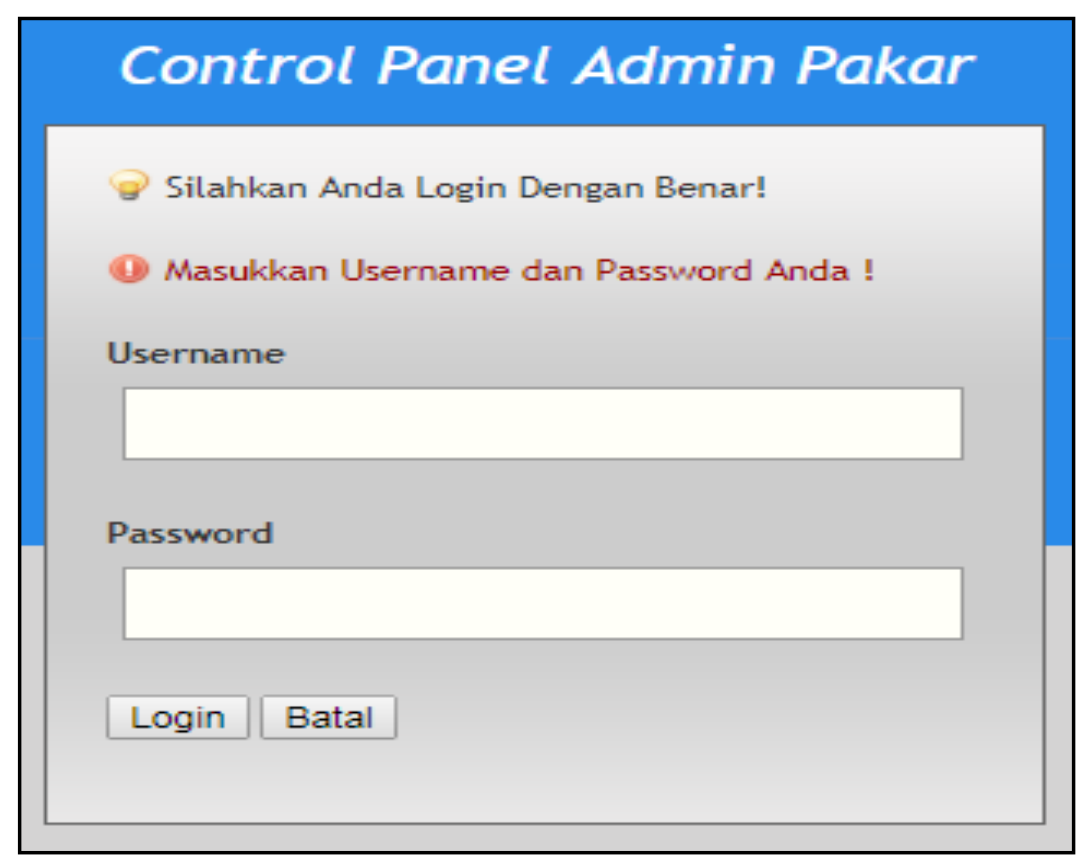

Gambar 7. Tampilan Halaman Login Adminitrator 
9. Halaman Utama Admin

Halaman ini merupakan halaman utama admin, yang terdiri dari beberap menu yaitu : menu dasboard, menu penyakit, menu gejala, menu relasi, menu update penyakit, menu update gejala, menu lap penyakit, menu lap gejala, dan menu logout sebaimana gambar di bawah ini :

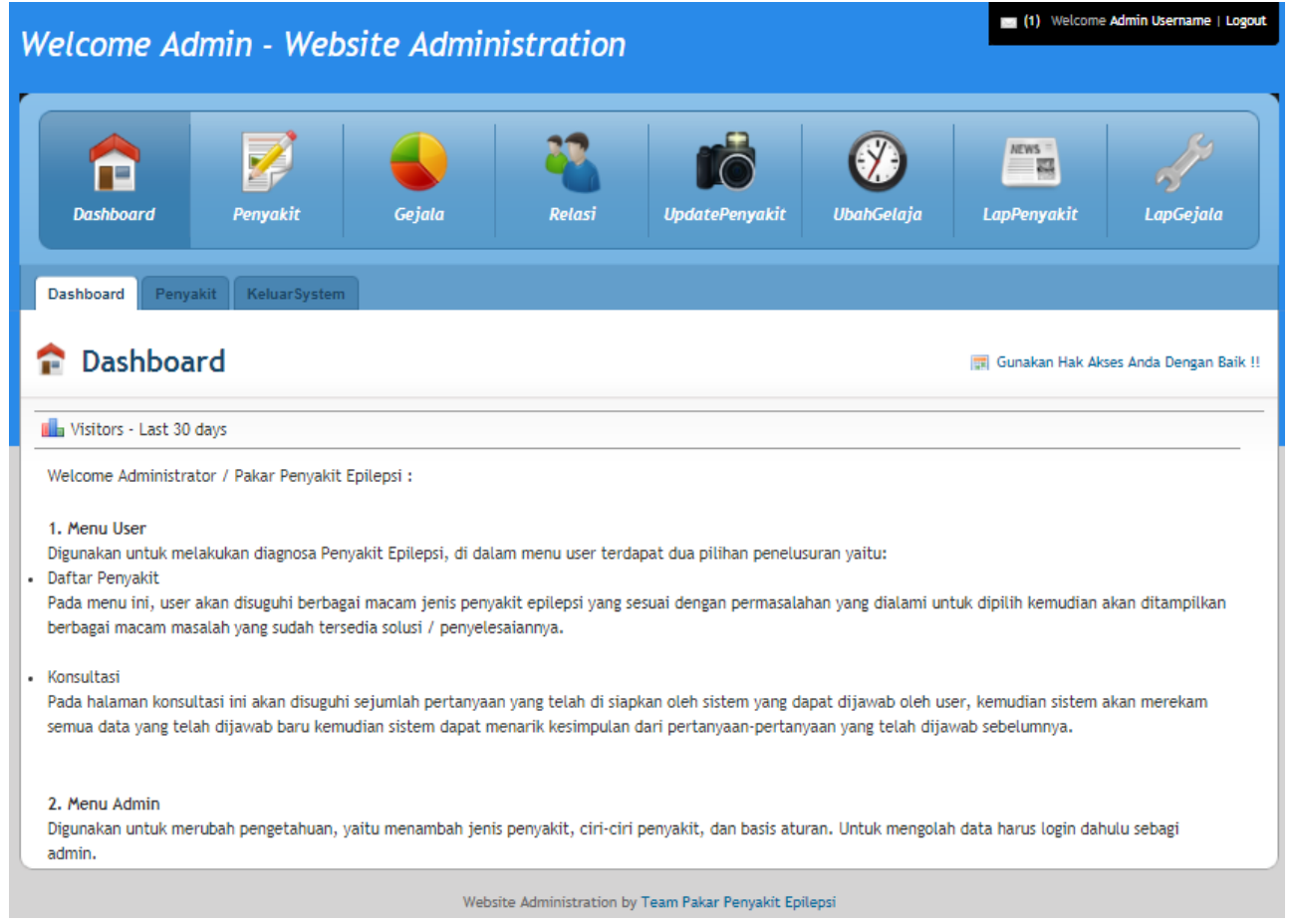

Gambar 8. Halaman Utama Admin

10. Halaman Tambah Penyakit

Halaman ini merupakan halaman untuk proses input data penyakit yang di input oleh admin setelah berhasil melakukan login. Pada halaman ini tersedia sebuah form input data dengan beberapa field. Untuk lebih jelas dapat dilihat pada gambar di bawah ini.

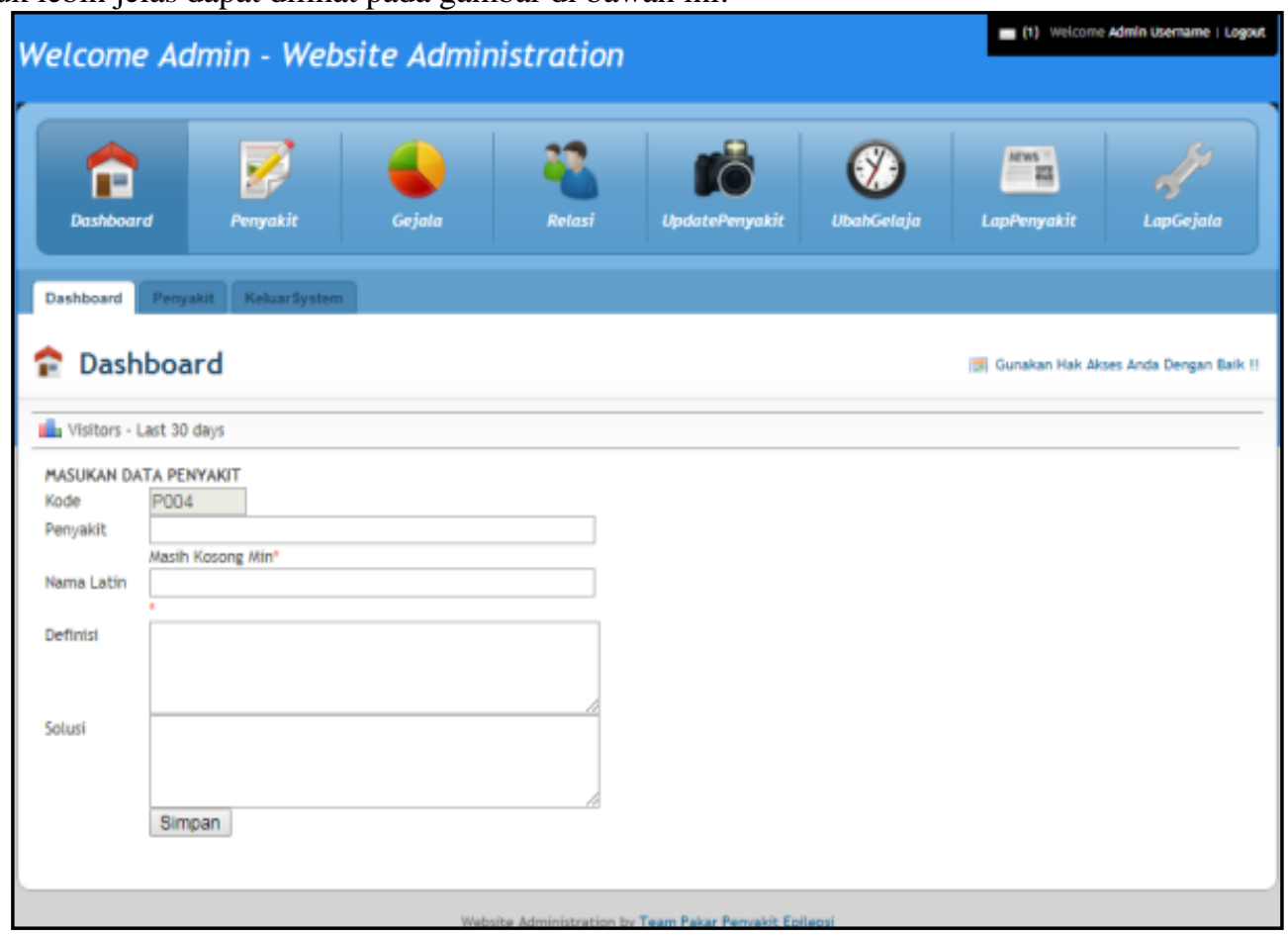

Gambar 9. Halaman Tambah Penyakit 
11. Halaman Tambah Gejala

Halaman ini merupakan halaman untuk proses input data gejala yang di input oleh admin setelah berhasil melakukan login. Pada halaman ini tersedia sebuah form input data dengan beberapa field. Untuk lebih jelas dapat dilihat pada gambar di bawah ini.

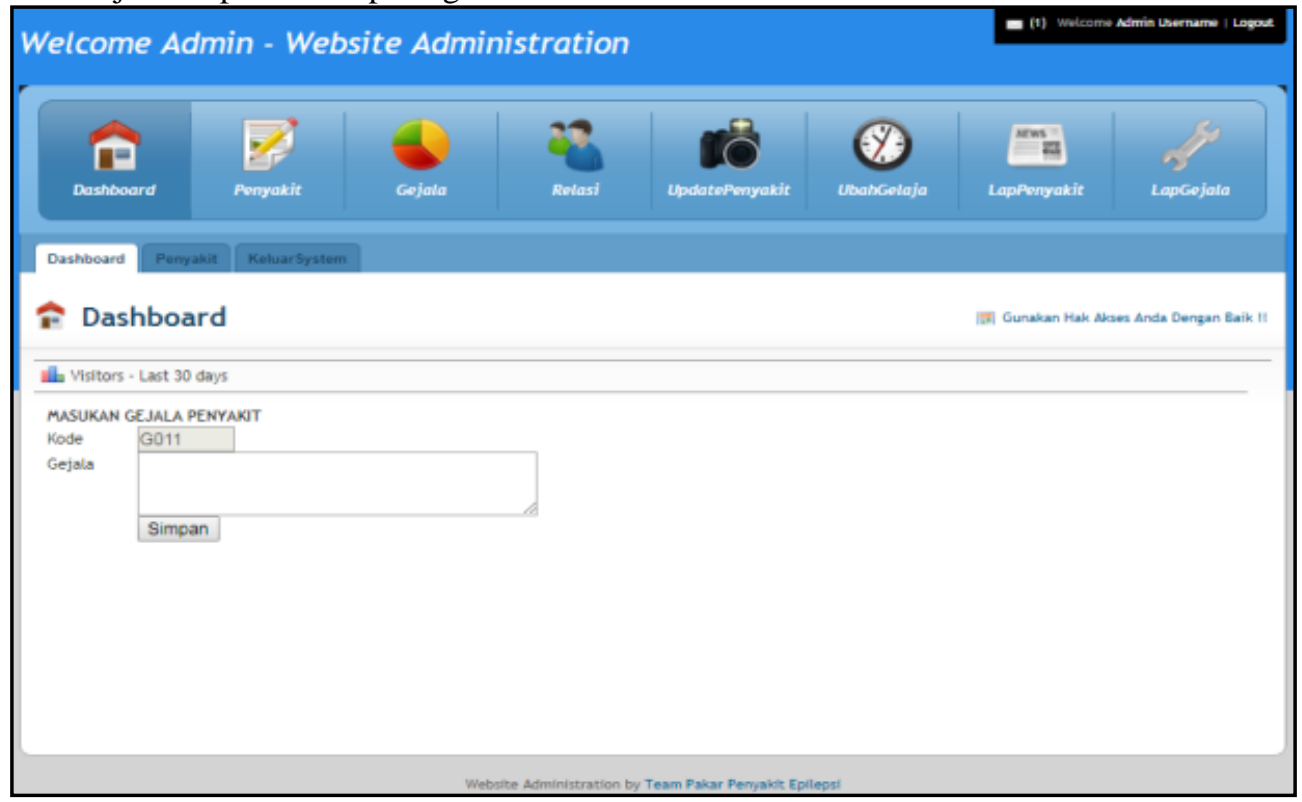

Gambar 10. Halaman Tambah Gejala

12. Halaman Tambah Relasi Solusi

Halaman ini merupakan halaman untuk proses input data relasi solusi yang di input oleh admin setelah berhasil melakukan login. Pada halaman ini tersedia sebuah form input data dengan beberapa field. Untuk lebih jelas dapat dilihat pada gambar di bawah ini.

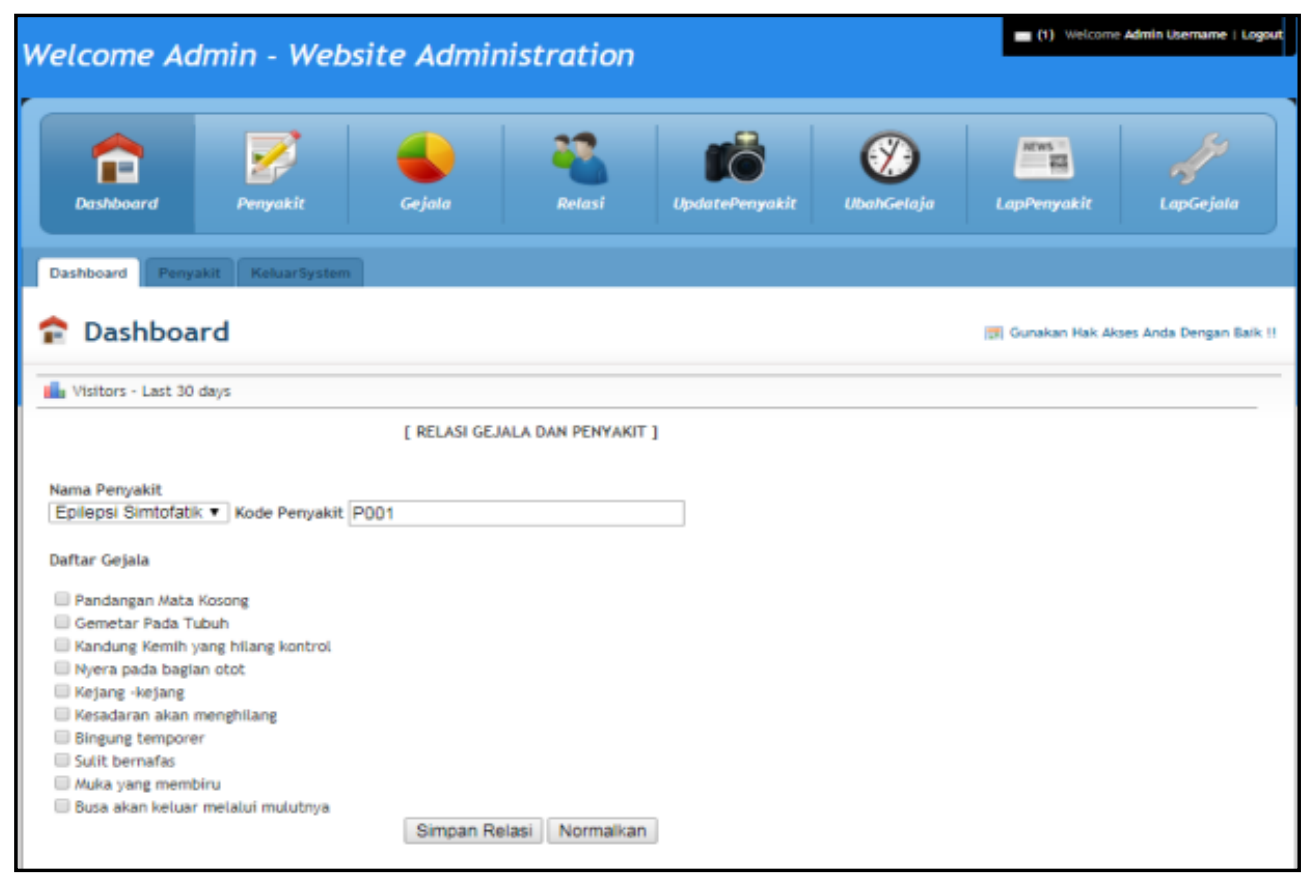

Gambar 11. Halaman Tambah Relasi Solusi

\section{Kesimpulan}

Berdasarkan penelitian yang telah dilakukan penulis mengenai perancangan dan implementasi Sistem Pakar Diagnosa Penyakit Epilepsi Menggunakan Metode K-Means Clustering Berbasis Web, maka dapat diambil kesimpulan sebagai berikut : 
1. Sistem pakar diagnosa penyakit epilepsi ini dibuat menggunakan pemrograman PHP dan MySQL sebagai basisdata.

2. Sistem yang dibuat berbasis online, sehingga dapat diakses dimana saja dan kapan saja.

3. Sistem yang dirancang dapat digunakan dalam konsultasi masalah penyakit epilepsi.

4. Pengembangan sistem pakar diagnosa penyakit epilepsi berdasarkan konsep Metode K-Means Clustering.

\section{Daftar Pustaka}

Andrian, C. (2019). Perancangan Kampanye Sosial Penanganan Anak yang Menyandang Epilepsi bagi Keluarga. Universitas Multimedia Nusantara.

Dasgupta, S. (2008). The hardness of k-means clustering: Department of Computer Science and Engineering, University of California ....

Hardiyanti, H. (2020). Hubungan Pengetahuan Orang Tua Dengan Tingkat Kekambuhan Pada Anak Epilepsi: Literature Review.

Kristanto, A. (2017). Epilepsi bangkitan umum tonik-klonik di UGD RSUP Sanglah Denpasar-Bali. Intisari Sains Medis, 8(1), 69-73.

Likas, A., Vlassis, N., \& Verbeek, J. J. (2003). The global k-means clustering algorithm. Pattern recognition, $36(2), 451-461$.

Lukas, A., Harsono, H., \& Astuti, A. (2016). Gangguan kognitif pada epilepsi. Berkala Ilmiah Kedokteran Duta Wacana, 1(2), 144-152.

Mulyawati, D. (2014). Evaluasi Penggunaan Obat Anti Epilepsi Pada Pasien Dewasa Di Instalasi Rawat Jalan Rumah Sakit Jiwa Daerah Surakarta Bulan Februari-Maret 2014.

Na, S., Xumin, L., \& Yong, G. (2010). Research on k-means clustering algorithm: An improved k-means clustering algorithm. Paper presented at the 2010 Third International Symposium on intelligent information technology and security informatics.

Pham, D. T., Dimov, S. S., \& Nguyen, C. D. (2005). Selection of K in K-means clustering. Proceedings of the Institution of Mechanical Engineers, Part C: Journal of Mechanical Engineering Science, 219(1), 103-119.

Purba, H. M., Siagian, L., \& Tarigan, J. (2017). Karakteristik Penderita Epilepsi Di Poliklinik Saraf RSUD Kabanjahe Tahun 2014-2015. Jurnal Kedokteran Methodist, 10(1), 45-49.

Sunaryo, U. (2007). Diagnosis Epilepsi. Wijaya Kusuma, I, 49-56.

Suwarba, I. G. N. M. (2016). Insidens dan karakteristik klinis epilepsi pada anak. Sari Pediatri, 13(2), 123128. 